epiphany

Journal of the Faculty of Arts and Social Sciences

International University of Sarajevo

ISSN 1840-3719 / No. 3 - Special Issue: Identity

Fall 2009

\title{
Identity Crisis: \\ Rudyard Kipling's Kim - A Postcolonial Perspective
}

\section{Ahmad M. S. Abu Baker Al al-Bayt University}

Kim is an elusive controversial text that generated a lot of contradictory criticism. Some critics regarded it as pro-Indian whereas others considered it antiIndian. Mark Kinkead-Weekes, for example, states that the novel is "the answer to nine-tenths of the charges levelled against Kipling and the refutation of most of the generalisations about him." He adds that "a whole kaleidoscope of race, caste, custom, and creed, all seen with a warm affection that is almost unique in Kipling" (Williams et al. 1994:480). To McClure, Kim "not only repudiates racist modes of characterisation, but also dramatises the repudiation, that is a Utopian portrayal of future racial harmony, and that it is perhaps a more effective antidote to racial antipathies than any of Conrad's works" (Williams, p.480).

Further, Abudul JanMohamed considers the novel as the one "which, above all others, explores the possibilities of bridging the gap which separates coloniser and colonised". To him, "[w]hat may initially seem like a rapt aesthetic appreciation of Indian cultures turns out, on closer examination, to be a positive acceptance and celebration of difference" (Williams, p.481). Edward Farley Oaten regards Kim as "the greatest masterpiece of journalism by the greatest living journalist", and Thurston Hopkins considers it a "tremendous Indian Novel ... surcharged with magic and fetichism of the East" and that "bristles with "native erudition and folk-lore"” (Singh 1974:77-78). 
Lynn Sunderland also invokes Eliot Gilbert's ideas in The Good Kipling. Gilbert warned of the "fallacy" of examining Kipling's work using "a narrowly political interpretation". Gilbert suggests that the "pressure upon him [Kipling] to turn out a developing political ideology is misplaced" and "reminds us that Kipling was essentially an artist, each story offering 'that internal order of its elements which is the only sort of consistency an artist need concern himself with'” (Sunderland 1989:29). Sunderland, however, acknowledges the presence of a "concept" that constitutes a "hierarchy" for Kipling. The "hierarchy" is defined as "the interlocking bonds of duty, responsibility, protection". It is also "a common language of ritual and symbol, a common respect for that particular type of honourable behaviour which Kipling called 'the Law'”. Sunderland admits, however, that Kipling "believed unswervingly in the abyss which separated men through border, breed and birth, and of which East and West was only one respect". She also claims that he "believed in the possibility of achieving momentary common ground through mutually recognized values", a belief that formed "the basis of his concept of hierarchy" (Sunderland, p.41, my italics).

Sunderland's remarks actually expose Kipling's racist attitude towards Indians. His belief in the "abyss" which separates different "breeds" of people, regardless of the premises upon which it is based, is racist in itself. Hence, Orwell maintains that to Kipling "almost all other races were 'lesser breeds without the Law"” (Gross 1972:92). Further, Sunderland admits that Kipling's “imperial mode of thought is so deeply ingrained that it actively alters his ability to perceive his escape [from the demands of the Empire] as freedom-it becomes instead a threatening distortion, a dangerous anarchy" (Sunderland 1989:43). One could argue that Kipling was willingly and consciously pro-Raj, and that he used his literary work as a vehicle to promote the Empire. One could also argue that he was unconsciously 
misled into adopting the imperialistic objectives of the Empire. In either case, the effect and the result remain the same: Kipling promotes the ideals of the Empire.

Charles Carrington is another critic who views Kim in a positive light. To him, Kim's education as a spy is not the subject of the novel. Rather, Kim is made to roam India to love it and make the readers love it, too. Carrington explains that “[p]olitics, the Empire, the Law, are taken for granted. It is not 'Kim's affair', nor the reader's, to question the credentials of the Pax Britannica, but to savour life within its borders". He also claims that in Kim "[n]othing is explained or excused or justified" (Carrington 1970:425-26). Taking the politics of the Empire "for granted" means taking Kipling's remarks at face value. Suffice it to say that Orwell called Kipling "the prophet of British Imperialism in its expansionist phase" (Gross 1972:91). Orwell's remark simply suggests that accepting Carrington's claim would limit and underplay the powerful discourse deployed in the novel and would simultaneously do a terrible injustice to Kipling's efforts in promoting the Empire.

In contrast, Williams warns that "a text so concerned with disguise, appearance and reality, magic and illusion should be so singularly adept at operating its own forms of textual disguise and illusion" (Williams et al. 1994:488). David Rubin also warns that "Kim is an endlessly beguiling book, but it should not be taken as in any way as a faithful picture of Indian life" (Rubin 1986:15). Further, Kipling's "love for India and his detailed delineations of Indian customs, people, and places often functions as smokescreens, disguising not only structures of power that underlie his work but his use of knowledge about India to perpetuate those structures"' (Hubel 1996:26). Said points out that in Kim "we can catch a great artist

\footnotetext{
' Kipling astonishes his readers by his picturesque technique which depicts India as a beautiful 'Oriental' place with its concomitant fetishisms and stereotypes. "Salman Rushdie has attested to the force and perceptiveness of much that Kipling wrote about India" (Lycett 2000). Kipling's knowledge of and fascination with India emanated from his childhood experience in India. "Kipling, like many Raj children, spent most of his time with Indian servants. He was so little conscious of difference that he had to be reminded to speak
} 
blinded in a sense by his own insights about India, confusing the realities before him, which he saw with such colour and ingenuity, with the notion that these realities were permanent and essential" (Said 1989:45, my italics). ${ }^{2}$ Kipling uses his knowledge of India to promote his ideal of an empire using his assumed insider's perspective.

The text juxtaposes the world of reality and that of imagination. Williams warns that the text creates what Barthes calls a "reality effect through its accumulation of detail, particularly of Indian life (and almost in the spirit of an ethnologist)" (Williams et al. 1994:488). Kipling creates a 'sham' of truth and authenticity by using his knowledge of some Indian ways of life to 'market' the Oriental stereotypes and colonial discourse. Although Kim is sometimes regarded as a work aimed at young boys rather than adults, I still believe it is a pedagogical tract intent upon glorifying Empire since it promotes such stereotypes that are fed into the minds of such young boys. Hence, although the narrator seems to speak from personal experience "thereby lending added weight to the condemnation", the text reiterates "the already-known truths of Oriental degeneracy" (Williams, p.486-87, my

English, rather than fluent kitchen Hindi, to his parents" (Lycett). Kipling was sent to a boarding school in England, which he hated and made his life miserable. Further, Kipling accepted his role as a coloniser for "he learned to be pukka. He had to, to survive. After that, there was no turning back" (Lycett). Kipling's childhood in India 'leaked' into his creation of the character of Kim. However, Kipling's knowledge of India is not comprehensive. "Kim's India, in spite of its picturesqueness, is the superficial India as an outsider sees it" (Singh 1974:78-79). Furthermore, "Kipling has caught and reproduced the picturesqueness of India, but he is more conscious of her 'inherent rottenness'. India has 'the merit of being twothirds sham; looking pretty on paper only"' (Singh, pp.79-80). Hence, Kipling and many other Anglo-Indian writers express in their literary works a desire to 'know' and 'understand' the 'real' India (Adela's desire to see the 'real' India in E.M. Forster's A Passage to India, p.67 being an example). India's "rottenness" is due to colonisation which impoverishes the masses by exploiting the riches of the land and leaving the people to hunger and starve living on crumbs that fall off the colonisers' tables. Kipling's knowledge of Indian ways of life and culture is exemplified in the following references from the novel: the trains in which "the sexes are very strictly kept to separate carriages" (p.39), the Indians who "sang to keep off evil spirits" (p.197), and those who "swore by the Djinns" (p.253), as well as the reference to "Dulhun, invisible about mosques, the dweller among the slippers of the Faithful, who hinders folk from their prayers" (p.255) and to the Jat who changed his son's name and "put him into girls' clothes" to protect him of the fever (p.267). 
italics). Further, Hubel remarks that "a text like Kim in fact reinforces the reality of India by seeing it so clearly as the other that imperial West must know and dominate" (Hubel 1996:87-88, my italics). The colonisers' racist attitude allows them to regard the natives as 'subhumans' or 'animals'. It also motivates them to gather information on the natives in order to subjugate and control them efficiently.

Kim also juxtaposes the cultural differences between the 'white' 'Christian' and 'civilised' British colonisers and the 'black' 'heathen' and 'savage' native Indians. Said notes the presence of an "absolute" "division between white and nonwhite, in India and elsewhere". He claims that "Kipling could no more have questioned that difference, and the right of the white European to rule, than he would have argued with the Himalayas" (Said 1989:10). Kipling could not "rid himself of that obsession, driven into the minds of all Englishmen who went East before the War, that a denial of racial superiority was the one deadly sin" (Rubin 1986:14, my italics). Garrat also notes that "Kipling allowed himself the most astounding generalizations about Indian duplicity and mendacity, or the physical cowardice of certain races" (Rubin, p. 14). Indeed, Kipling calls for a realisation of the 'genetic' differences between white Sahibs and Indians.

The novel promotes the colonial assumption that cultural differences between races are genetic. Kipling uses his knowledge of the natives and their ways of life to prove that colonisers who are born in India and live with its people are more capable of understanding natives than 'imported' ones. Hence, Williams remarks that "the book [Kim] is a plea on behalf of the country-born Englishman (who is, born and bred in India), as the rightful ruler, rather than the 'genuine imported Sahib from England" (Williams et al. 1994:495, my italics). This 'plea' is an attempt by the coloniser Kipling to legitimise the British colonial presence in India. It is also an

\footnotetext{
${ }^{2}$ Further, Williams remarks that the novel renders "the representation of the Orient and its inhabitants as static, unchanging, incapable of change" (Williams et al. 1994:482).
} 
exclusive discourse by which all other colonisers are excluded from sharing the spoils of colonisation. ${ }^{3}$

Kipling, like all colonisers, has to convince himself of the legitimacy of colonisation. He wants to justify and rationalise colonising the natives. Said warns that "if one reads Kipling ... as someone who had read Frantz Fanon, met Gandhi, absorbed their lessons, but had remained stubbornly unconvinced by both, then one seriously distorts the defining context in which Kipling wrote". However, he maintains that "it is true to say" that Kipling's fiction "represents both the Empire and conscious legitimizations of it"4 (Said 1989:24, my italics). Teresa Hubel states that "as a white, middle-class, male writer, Kipling himself benefited from British imperialism" (Hubel 1996:26). Said notes the "unquestioned axioms of modern life" to the "monuments of nineteenth-century European culture". These axioms emphasise "the necessity of Empire to England's strategic, moral and economic wellbeing" and simultaneously depict "the dark or inferior races as thoroughly unregenerate, in need of suppression, severe rule, indefinite subjugation" (Said, p.29-30). This type of depiction also stems from the colonisers' need to legitimise colonisation. $^{5}$

In the following sections, Kim's identity crisis and his chameleon-like nature will be explored by observing Kim's relationships with the natives. Also, his Hamletlike indecision and his final decision to be a coloniser will be highlighted and explained.

\footnotetext{
${ }^{3}$ This is reflected in the novel by the Russian threat to the British presence as an imperial colonial power in India.

${ }^{4}$ Further, Said remarks that "for him [Kipling] it was India's best destiny to be ruled by England" (Said 1989:23). He also explains that "Kipling was not a neutral figure in the AngloIndian situation, but a prominent actor in it" (Said. p.11).

${ }^{5}$ Jean-Paul Sartre asks, "How can an elite of usurpers, aware of their mediocrity, establish their privileges?". To him, the only means to achieve that is by "debasing the colonized to exalt themselves, denying the title of humanity to the natives, and defining them as simply absences of qualities - animals, not humans" (Memmi 1974:xxvi).
} 


\section{Kim and the Natives}

It is symbolic that the novel begins with Kim and his Indian friends playing under Zam-Zammah (the cannon). This scene foreshadows the tensions between Russia and Britain and positions the novel as a war novel. In the novel, war is referred to as "punishment" (p.35) and, as Kim describes it, "chastisement" (p.68) whereas peace is referred to as being a chance for the enemy to become stronger (p.35). The cannon is "always first of the conqueror's loot" (p.1). Figuratively speaking, it represents the colonial hierarchy. "[T]he English held the Punjab" (p.1), and therefore, Kim gets on top of the cannon and the Muslim Indian boy, Abdullah, has to get off it. Kim explains that "[a]II Mussalmans fell off Zam-Zammah long ago!" (p.5). He also remarks that "the Hindus fell off Zam-Zammah too. The Mussalmans pushed them off" (p.5). The cannon becomes a Wheel of Fortune upon which cultures and nations rise and fall. In this scene Kipling is carefully defining and asserting the colonial hierarchy and English dominance before writing about hybridity where lines between races and classes become blurred.

Kim is the child of a "young colour-sergeant of the Mavericks, an Irish Regiment" (p.2). Kim is born "Between first and second cockcrow of the first night in May", and his first cry causes "the great earthquake in Srinagur" (p.56). This supernatural birth had/has a drastic destructive effect on India. ${ }^{6} \mathrm{He}$ is a mysterious 'creature' with 'evil' supernatural powers, an idea that is emphasised by the many references to him as being a "Shaitan" or a "devil". Kim's identity is a 'hard nut' (p.204) to crack. He is 'culturally' Asian and 'genetically' European. He "borrowed

\footnotetext{
${ }^{6}$ Kim's prophecy contains "a red and angry sign of War" (p.57). Consequently, he "brought luck [war]" to India (p.138). In addition, the earthquake caused by his birth echoes what New Historicism considers as an 'absence' of one 'real' history, and the 'presence' of different representations of history or 'histories'.
} 
right-and left-handedly from all the customs of the country he knew and loved"7 (p.104). The combination of the Asian and the European affects Kim culturally. His identity crisis is caused by the native culture to which Kim feels so 'related'. Hence, he accuses Mahbub Ali of "selling" him "back to the English. What will they give thee for blood-money?" (p.156 my italics). To him, Mahbub Ali is a 'traitor' who betrayed him into the hands of the British. Hence, Lurgan "treated Kim as an equal on the Asiatic side" (p.215). Further, "Kim was in the seventh heaven of joy to see all India as he was walking on the Great Road" (p.89). These references demonstrate how close he feels to the Indians, though he maintains his superiority over them.

It is ironic that Kim is called "Friend of all the World" (p.6). His relationships with the natives are largely characterised by contempt. He treats his "friends" and every other character with contempt except for the lama whom he loves, a love that does not prevent him from exploiting him. Kim's contempt of the natives is revealed in many cases. He "consorted on terms of perfect equality with the small boys of the bazaar" (p.1). Yet, he kicked the Indian boy off the cannon and took his place, because he is English and "the English held the Punjab" (p.1). The narrator explains that "India is the only democratic land in the world" (p.5 my italics). To him, democracy is achieved since the Indian boy, whose father is a rich man, cannot remove Kim, the poor boy, off the cannon. Williams, however, warns that this is "simply one more restatement of the (democratic) right of the white man to kick the

\footnotetext{
${ }^{7}$ The more time Kim spends with the natives the more he borrows from their habits. "Each long, perfect day rose behind Kim for a barrier to cut him off from his race and his mother tongue. He slipped back to thinking and dreaming in the vernacular..." (p.304 my italics). However, his superiority over the natives remains unquestioned. In addition, he can "salaam" like an Oriental (p.97) use a twig "as a tooth-brush" (p.104), squat "as only the natives can" (p.143), rely "Oriental fashion, on time and chance" (p.150), spit "red pan-juice" (p.47), and he yearns "for the caress of soft mud squishing up between the toes" (p.178). Like an Indian, he "snapped his fingers mechanically to avert whatever evil" (p.259), is used to the "indifference of native crowds", feels a "strong loneliness among the white men" (p.146), is happy with his bed among the trucks of Mahbub's animals which "would not appeal to many white boys" (p.195), and joins "the Kentish-fire of good wishes and bad jokes" for a married couple (p.88).
} 
native, however rich he may be" (Williams et al. 1994:483). Kim is like Mowgli or Tarzan among the Indians. Mowgli and Tarzan establish their superiority over both the natives and the animals. Kim does the same, and his superiority remains unquestioned.

Sarup considers identity as "fragmented full of contradictions and ambiguities". He differentiates between "public" identity, "[t]he 'outside' of our concept of self", and "private" identity, "the 'inside' of our identity". He calls the process of categorising people. "People attach certain labels to others, and labels often (but not always) begin to have an effect" [my italics] upon the way people think of others. Further, Sarup gives two models of identity:

a 'traditional' view that all dynamics (such as class, gender, 'race') operate simultaneously to produce a coherent, unified, fixed identity. The more recent view is that identity is fabricated, constructed, in process, and that we have to consider both psychological and sociological factors. (Sarup 1996:14)

"Labeling" is a component of stereotyping. It blocks any chance of assimilation between different nations. Reasons for this may include having different and rival monotheisms (as in the case of Christianity and Islam) as well as racism among others. Hence, Sarup's choice of the words 'often' and 'not always' are perhaps not so precise.

Accordingly, Kipling's Indian diatribes maintain that the "inconceivable filth of mind [in which] the peoples of India were brought up from the cradle" and "the immeasurable gulf that lies between the two races in all things" explain "how it comes to pass that the Englishman is prone to despise the natives" (Lycett 2000, my italics). These words expose the strength of stereotypes and their guaranteed 
repeatability. All natives are fed this 'filth of mind' 'from the cradle'. The English are, therefore, excused in being 'prone' to despise the natives.

Although Kim considers himself a Sahib, he is discriminated against and treated badly and with contempt at St. Xavier which "looks down on boys who "go native altogether.' One must never forget that one is a Sahib, and that someday, ... one will command natives"8 (p.177, my italics). Clearly, at St. Xavier school racism is fed into the children who are being prepared to rule the natives. Consequently, the drummer-boy styles all natives as "niggers" (p.141). Kim nearly "goes native altogether", and has, therefore, to be taught a hard lesson. The drummer-boy beats him and treats him badly because Kim can "talk the same as a nigger". He also describes him as "an ignorant little beggar" who was "brought up in the gutter" (p.145). Further, Kim was subjected to two-thirds of the "white man's abuse' at St. Xavier" (p.150). He learns to maintain his superiority over the natives the hard way.

Kim is another Titus Andronicus. He believes he is better than everybody, even his own Irish or Indian peoples. He switches sides to work for the colonising enemy manifested in the British Secret Service. Hence, Edmund Wilson states that "Kim returns to the British Secret Service as, in effect, an enforcement officer for British imperialism against the Indians among whom he has lived and worked" (Childs 1999:23). To the same effect, Mohanty claims that Kim, like Mowgli, becomes an "accomplished insider without having given up any of his privileges as an outsider" (Childs, p.243). He explains that Kim and Mowgli are taught "to inhabit perfectly without being tied down to the place of their habitation .... A strange allegory of colonial rule as possession without implication, penetration without involvement" (Childs, pp.244-247). Kim chooses to join the British Secret Service and to work against the Indians just like Titus Andronicus in Shakespeare's play Titus

\footnotetext{
${ }^{8}$ Edward Said notes that "a white middle-class Westerner believes it his human prerogative not only to manage the nonwhite world but also to own it" (Said 1987:108, my italics).
} 
Andronicus fights with the enemy against his own people. His "white blood" (p.255) prevails in the end, and this enforces Kipling's belief in the genetic differences between races.

Mahbub Ali asks Kim, "who are thy people, Friend of all the World?" Kim as a coloniser is related to the 'land' and not to the people. Hence, he declares, "[t]his great and beautiful land" (p.193). This answer maintains the dividing line between Kim and the natives. He cannot 'erase' his white culture. Hurree, therefore, informs him that "If you were Asiatic by birth you might be employed right off; but this halfyear leave is to make you de-Englishised" (p.262). Kim is also afraid snakes, because "[n]o native training can quench the white man's horror of the Serpent" (p.61). These references emphasise Kim's inability to escape his white blood. His genetics resolve the identity crisis, thus answering the lama's question "can earth be stronger than Mother Earth?" (p.372)

Kim's identity crisis is reflected in the way his mind functions. He "usually" thinks "in Hindi" (p.213), but when Lurgan tries to dazzle him into believing that a broken jar is moving, he shifts from Hindi to English. "[H]is mind leaped up from a darkness that was swallowing it and took refuge in - the multiplication-table in English" (p.218). The White culture, the white language, and the white blood are so 'superior' that they make Kim invulnerable to superstitions, illusions, and the effect of years of living among the natives. In addition, when Kim is angry or relaxed he thinks like an Oriental in Hindi, but when he is confused and needs to rationalise things, he thinks in English. ${ }^{9}$

Kim's identity crisis is also exposed whenever he 'forgets' he is a Sahib. The "Eastern" smells of Lurgan's room make him "forget he was to be a Sahib" (p.211). When he says goodbye to the lama at the Gates of Learning, he is "all forgetful he 
was a Sahib" (p.174). Later, he "remembered he was a white man" (p.349). At the Jain temple, he stoops "Mohammedan fashion" thus "forgetting St. Xavier; forgetting his white blood; forgetting even the Great Game" (p.271). Hence, he is confused and cannot understand who/what he is. He wonders, "Who is Kim-Kim-Kim?" (p.265) and asks, "I am Kim. I am Kim. And what is Kim? His soul repeated it again and again" (p.403). Further, he confesses to the Shamlegh woman that "I have wrestled with my soul till I am strengthless"10 (p.377). Kim cannot come to terms with the conflicting cultures and identities that clash inside him and which he has to use to define his identity. ${ }^{11}$

Jacques Derrida claims that "[o]nce the center or the origin have begun repeating themselves, by redoubling themselves, the double did not only add itself to the simple. It divided it and supplemented it." Hence, "[t]here was immediately a double origin plus its repetition." He adds that "[t]hree is the first" and the "last" "figure of repetition" because "the abyss of representation always remains dominated by its rhythm, infinitely". To him, the figure "two" continues to be an "indispensable and useless articulator of the book". It is "the sacrificed mediator without which triplicity would not be, and without which meaning would not be ... different from itself; in play, at stake" (Derrida 1978:299-300). Also, Derrida notes that "only by means of a series of words that are faulty" and which he "erased in

\footnotetext{
${ }^{9}$ When Kim returns to the lama as a scribe and spends the night at the Jain temple, "he dreamt in Hindustanee, with never an English word" (p.276 my italics). Indeed, Kim's choice of language depends on whether he is stressed or relaxed.

${ }^{10}$ More to the point, a long-haired Hindu holy man "sadly" informs Kim that "I also have lost it ... It is one of the Gates to the Way, but for me it has been shut many years." He explains to the "abashed" Kim that "[t]hou wast wandering there in thy spirit what manner of thing thy soul might be. The seizure came of a sudden." Kim announces that he is "a Seeker", and adds, "though Allah alone knoweth what I seek'" (pp.265-66). Here too, Kim's identity crisis is evident, a crisis that is so severe that it is depicted as a sudden "seizure".

11 "[M]ass migration and market globalization have produced a vast array of transformations in civil society, the state and the nation; citizens have to rewrite and rethink their identities" (Elbaz 1995, my italics). Mercer claims that "identity only becomes an issue when it is in crisis, when something assumed to be fixed, coherent and stable is displaced by the experience of doubt and uncertainty" (McCrone 1997:581). An identity crisis becomes more
} 
passing, in measure, regularly" yet "leaving them to the force of their tracing, the wake of their tracement (tracement), the force (without force) of a trace that will have allowed passage for the other" was he "able to arrive at the end" of his "phrase" (Derrida 1991:424). This 'erasure' causes the 'play' of the 'centre'.

The 'presence' of Kim's 'native' self means an 'absence' of his 'English' or 'Sahib' self and vice versa. Hence, his identity is, therefore, "a sort of nonlocus in which an infinite number of sign-substitutions came into play" (Derrida 1978:280). These two selves form the binary opposition Native-Kim/English-Kim. Each of Kim's characters exists in a state of 'différance' with the other. ${ }^{12}$ Hence, Kipling shatters the unity, solidarity, and coherence of 'identity'. The 'presence' of both characters in Kim removes or 'erases' the slash (/) separating the binary Native/English and allows the 'centre' to 'play' by creating a 'third' or 'triple' text manifested in the body of Kim.

The 'identity' of Kim is without fixed contours. The colour of his skin, a race marker, is undecided and is, therefore, very hard to imagine. He is "burned black like any native" (p.1), but "not very black" (p.121). Simultaneously, he is a "white boy" (p.124), has "white blood" (p.255), and is "certainly white" (p.122). Yet, he is a "bonze" (p.356) and a "scarlet figure" (p.150). He is Irish by birth"13, Asiatic by culture and yet he is treated as Englishman. Indeed, he is an embodiment of Keats' “'negative capability”" (Childs 1999:252). These conflicting characteristics give him

intensified in hybrid multi-cultural societies where more than one nationalism exists within the same boundaries.

${ }^{12}$ Kipling uses the theme of the double, which is so common in late $18^{\text {th }}$ and $19^{\text {th }}$ century literatures. Like Dr. Jeckyle and Mr. Hyde, Kim changes from his Indian into his British character. Even Kim's shape changes according to the lama. Kim seems to have a schizophrenic identity, each identity acting like an alter-ego of the other. Kipling reflects this duality in the beginning of chapter eight of the novel when he writes: "But most to Allah Who gave me two / Separate sides of my head" (p.186).

${ }^{13}$ Kim's anger wakes "every unknown Irish devil" in his blood (p.346). Kim is considered as Irish when he attacks the Russians because it is not 'civilised' to beat another European. Further, funny situations "tickled the Irish and the Oriental in his soul" (p.354). This suggests that Sahibs are always serious. 
"a lusus naturoe" (p.138) or a "chameleon-like" character as Said describes it (Said 1989:42). Indeed, his perplexing descriptions make figuring out who/what Kim is a "tremendous puzzle" (p.265). The colour of his skin as a form of identity is 'erased' thus making him anonymous. Consequently, he attains the freedom of transcending ethnicity and identity..$^{14}$

Indeed, Kim does not have a unified and clearly defined religious or social identity. Kim asks, "am I a Hindu?" (p.27). He also asks Mahbub Ali, "What am I? Mussalman, Hindu, Jain, or Buddhist? That is a hard nut" (p.204 my italics). Even Mahbub Ali, who is like a father to him, cannot realise who/what Kim is. Hence, he asks the lama about Kim's “country - his race - his village? Mussalman - Sikh Hindu - Jain - low caste or high?" (p.28). Kim, however, does not assume a fixed identity of any kind. Hence, he informs Mahbub Ali that "I will change my faith and my bedding, but thou [Mahbub] must pay for it" (p.186). Only when Kim decides to become a coloniser, does he acquires a fixed identity.

Kim goes through a process of 'unstable' metamorphosis. Kipling shatters the concept of 'physical' identity by depicting Kim as a "child" (p.388), a "shameless beggar-brat" (p.306), a "magician" (p.365) and a "man" (p.271) who is very old since "[e]very month" Kim "become[s] a year more old" (p.195). Since Kim can grow a year older each month then the concept of 'time' is shattered as well. Further, he can "change swiftly" his physical appearance (p.129). He is described as "bearing two faces - and two garbs" (p.47) and two different "kinds of faces" (p.203). In addition, the lama cannot tell whether Kim is "a spirit" or "an evil imp" (p.86).

${ }^{14}$ Other conflicting characteristics of Kim include: being a "European" (p.316) with "the European's lust for flesh-meat" (p.277), a "Sahib" (p.144), an "English boy" (p.125) who is "Irish enough by birth"(pp.51-52), an "Oriental" (p.314) with the "Oriental's indifference to mere noise" (pp.198-99), a "native" (p.121), a "casteless Hindu" (p.96), "Asiatic" by culture but not by birth (p.262), someone who "spoke the vernacular" (p.1), a "wild animal" (p.146), an "imp" (p.136), a "true prophet" (p.85) and a "malignant liar" (pp.96-97). These characteristics render Kim as nearly an embodiment of Darwin's "Missing Link" especially in 
More to the point, the lama asks Kim if he "wilt return in this very same shape?" (p.50). He also announces that Kim looked "[a]s a boy in the dress of white men - when I first went to the Wonder House. And a second time thou wast a Hindu. What shall the third incarnation be?" (p.129, my italics). Mahbub Ali also warns Kim to "'remember this with both kinds of faces. Among Sahibs, never forgetting thou art a Sahib; among the folk of Hind, always remembering thou art-' he paused, with a puzzled smile" (p.203). "It needs only to change his clothing, and in a twinkling he would be a low caste Hindi boy" (p.153), or be transformed from a Mohammedan horse-boy into a Eurasian lad (p.208). Kim becomes a mysterious entity that seems capable of changing its physical characteristics just like a chameleon. Kim becomes some sort of supernatural creature that is probably not "woman-born"15 (p.99).

\section{Kipling's Hamlet: "Thatt is The Question!"16}

'Do I dare disturb the universe? I am not prince Hamlet'

T.S. Eliot's "The Love Song of J. Alfred Prufrock"

'This is the great world, and I am only Kim. Who is Kim?'

[Kim ch.7.167]

Hurree quotes Shakespeare's prince Hamlet when he remarks that "Thatt is the question" (p.314). This quote encapsulates Kim's identity crisis. Kim is another

those references to Kim as an imp. Is it a coincidence that Kim ends up working as a "chainman" (p.251)?

${ }^{15}$ His supernatural status is emphasised by his depiction as a "shameless son of Shaitan" (p.180), a "Shaitan" (p.206), a "devil" (p.171), a "limb of Satan" (p.137), a "most finished son of Eblis" (p.189).

${ }^{16}$ Kim contains references to Shakespearean plays such as Titus Andronicus, Lear, and Julius Caeser. The characters in the novel shift between being participants in the action and being an audience, such as when Kim disguises E.23 on the train. This technique is similar to Shakespeare's a-play-within-a-play, as in Hamlet for instance. The play-within-a-play is suggested when Kim and the lama "entered a world within a world" (p.334). It is also suggested by the reference to "European audiences" (p.306), and in Kim's "performance in character of that holy man"” (p.232 my italics). Hence, the novel becomes a stage with an audience and actors. 
Hamlet "wrestling with [his] soul" (p.377). He cannot decide whether he wants 'to be' a Sahib with "the dignity of a letter and a number" (p.230), or 'not to be' a Sahib and become a colonised native. He resolves his identity crisis by choosing to become a coloniser. His decision is implicitly stated when he breaks down and tells the lama "I love thee... and it is all too late" (p.388). The lama, however, has already felt Kim's metamorphosis into a Sahib. "Now I look upon thee often, and every time I remember that thou art a Sahib. It is strange" (p.386). Kim remains in denial at this stage and reminds the lama that "I am not a Sahib. I am thy chela, and my head is heavy on my shoulders" (p.386). This reference indicates the moral identity crisis Kim is negotiating.

The lama feels Kim's crisis and its concomitant sadness. He assures him that "[t]hou hast never stepped a hair's breadth from the Way of Obedience". He also explains that "[i]t is the Body ... that speaks now. Not the assured Soul ... Know at least the devils that thou fightest. They are earth-borne-children of illusion" (p.388 my italics). The lama is not aware that Kim's sadness is a result of the way he used him for his Game. Kim already knows the devils he is fighting with, and his sadness is a result of his awareness of the futility of escaping his 'white blood'. ${ }^{17}$

Kim shifts between the coloniser who accepts his role and the one who refuses it. For instance, he regretfully remarks that "I wish I did not come here to find the Red Bull and all that sort of thing. I do not want it" (p.130). He also declares that "I do not want to be a Sahib" (p.152), and that "I am not a Sahib" (p.192). On the other hand, he tells Hurree that "I am a Sahib" (p.315), and he remarks "I am a Sahib and my heart is heavy too" (p.144). Kim, however, has always had the 'genetic'

\footnotetext{
17 The lama's subsequent words reveal his feeling that Kim is lying about something. He teaches Kim that "[t]here are many lies in the world, and not a few liars, but there are no liars like our bodies, except it be the sensations of our bodies" (pp.388-89 my italics). The lama could be referring to the way Kim pretended to burst in tears to beg for a train ticket earlier in the novel. Kim was so persuasive that his tears ran down his cheeks. Did the lama develop a "doubt-zone" for Kim after that incident?
} 
tendency or the 'psychological readiness' to become a coloniser, and therefore, he decides to become one.

There are many references that foreshadow Kim's decision. For instance, he announces that "I will be a Sahib" (p.193), and he "swore to himself in the language of St. Xavier's" (p.280). Also, he "would be a Sahib again" (p.210), and he asks Lurgan's Hindu boy "Is this the way to lie to a Sahib?" (p.213). He also warns him that "I will beat thee in the morning. I do not love Hindus" (p.213). Kim graduates from the school of Sahibs, and therefore, adds violence and hatred to his treatment of the natives, which before his school years was only characterised with contempt. ${ }^{18}$ Kim's 'genetic' readiness to become a coloniser is evident in his 'instinct' for the desire of knowledge and power. Hence, "he wished to investigate" (p.111) and following "his instinct, stretched out to listen and watch" (p.10 my italics). He quickly feels at home with the colonisers. He shouts "farewells excitedly" when the soldiers leave him among their women and children. "Life as a Sahib was amusing so far" (p.139). Further, Colonel Creighton and Mahbub Ali describe him as a polo pony that "knows the game [of Secret Service] by divination" (p.161). Even during the very tense moment between Kim, Mahbub Ali and Creighton, Kim did not feel 'inferior' to either of the two men. "[I]t never occurred to him to throw himself on the white man's mercy or to denounce the Afghan" (p.154). These references demonstrate his 'genetic' readiness to assume his role as a coloniser, and again, confirm Kipling's theme that "once a Sahib always a Sahib"19 (p.151).

\footnotetext{
${ }^{18}$ Other examples include: If Kim chooses, "he could escape into great, gray, formless India .... Meantime, if the Sahibs were to be impressed, he would do his best to impress them. He too was a white man" (p.135). The words 'gray' and 'formless' reflect the 'lusus' nature of India and Kim. In addition, "Benares struck him as a peculiarly filthy city" with "narrow stinking streets" after leaving St. Xavier (p.266 my italics), and he announces that "I have accomplished the years appointed for a Sahib" (p.272). More examples can be found in (p.244), (p.269), (p.180), (p.184), (p.362), and (pp.379-80). All the above references prove that Kim begins to accept his role as a coloniser.

19 Other examples of Kim's 'genetic' or 'psychological readiness' to become a coloniser include his tendency to exploit the natives. The Kulu widow accuses him of sticking "to the
} 
When Kim decides to become a coloniser Sahib, he also adopts the coloniser's religion (Christianity) just like the Shamlegh woman did. Hence Kim remarks that:

'I am to pray to Bibi Miriam, and I am a Sahib' ... 'No; I am Kim. This is the great world, and I am only Kim. Who is Kim?' He considered his own identity, a thing he had never done before, till his head swam. He was one insignificant person in all this roaring whirl of India, going southward to he knew not what fate. (p.167, my italics)

Kim is not content to be "one insignificant person" in India. Therefore, he decides to become a coloniser Sahib with the privileges of power and authority. Yet, though Kim is supposed to be a Christian, he acts in a "Mohammedan fashion" whenever he "forgets" he is a Sahib. He, for instance, "stooped, Mohammedan fashion" at the Jain temple (p.271), and he started "shampooing his [lama's] feet, Mohammedan fashion" (p.359). In addition, he unconsciously utters words like "Allah be merciful" (pp.401-02), "Allah Kerim!" (p.413), and "Allah alone knoweth what I seek" (pp.26566). Further, he starts "muttering a Mohammedan invocation" (p.289) while disguising E. 23. Consequently, Hurree reminds Kim that "when next time you are under the emotions please do not use the Mohammedan terms with the Tibet dress"20 (p.402 my italics).

The effect of Islam on Kim results from his association with Mahbub Ali. Mahbub Ali becomes, in a sense, responsible for the 'production' of the

Holy One for the sake of gain" (p.96), and he confirms it when he asks, "Do we not all work for gain?" (p.96). Further, he does not give the museum a "title-such as Lala or Mian. He could not divine the man's creed" (p.7), and he has the power as a coloniser to defy the sacred "Brahminee bull" (p.19). No Indian dares to defy the sacred beast no matter what religion he/she belongs to. He enjoys "the sense of power" (p.67), and treats the natives with contempt. Other examples are found in (p.98) and (pp.116-117).

${ }_{20}$ More examples include: "Kim stood up, externally at least, a Mohammedan" (p.186 my italics). He "found it easier to slip into Hindu or Mohammedan garb when engaged on certain businesses" (p.4). Mahbub Ali, though sarcastically, remarks that Kim "might mount Mohammed's Horse and fly away" (p.407). 
coloniser Kim. Their relationship is described as that of a father and son (pp.251, 253). Mahbub Ali gives him a revolver as a gift and encourages him to kill. He remarks "and please God, thou shalt someday kill a man with it" (p.244). He also teaches him to write the report and the map (p.242). Despite this close relation, Kim remains 'superior' to him. Kim reminds him that "no Sahib must tell a black man that he has made a fault" (p.192). Mahbub Ali also uses "the tone he used towards Europeans" to remind Kim that "I am a Pathan; thou art a Sahib and the son of a Sahib" (p.209), and his fear of Kim is revealed when he asks, "Wilt thou some day sell my head for a few years sweetmeats if the fit takes thee?" (p.206).

The previous examples demonstrate the effect of the Muslim Mahbub Ali on Kim. This effect makes the readers, the 'audience' of the novel, hold Mahbub Ali, and not the British colonial regime, responsible for Kim's transformation into a Sahib. The reason for such a 'manoeuvre'21 probably stems from the Christians' animosity towards Islam. ${ }^{22}$ Like Buddhism, Islam is also a threat to Christianity and to the colonial regimes in Europe. Hubel, however, remarks that in Kipling's work "Muslims are valorized because they belong to a so-called 'martial race', which once ruled a huge part of the country, while Hindus, and particularly Bengalis, are criticized or even ridiculed" (Hubel 1996:31). Kim has to 'study' and 'know' Muslims like Mahbub Ali to be able, as a coloniser, to control them. His unconscious Muslim remarks associate Islam with his transformation into a coloniser. This association is revealed in Kim's training which is mostly done by Mahbub Ali and Lurgan whereas Colonel Creighton, who stands for the British Raj, remains distant.

\footnotetext{
${ }^{21}$ The reference to the German soldier, one of "the many guests of the woman" who raised Kim, is a similar manoeuvre. He is to be held responsible for Kim's racism against the natives. This German had been "on the barricades in Forty-eight". He teaches Kim to write in return for food. "Kim had been kicked as far as single letters, but did not think well of them" (p.140). The German's influence on Kim during Kim's childhood, as Kipling seems to suggest, justifies Kim's racism against the natives and his choice to become a coloniser as well. Through this excellent manoeuvre, Kipling makes the British colonisation not guilty of Kim's racism or transformation into a coloniser Sahib.

${ }^{22}$ Said remarks that "for Europe, Islam was a lasting trauma" (Said 1987:59).
} 
Kim's search for his identity and for his role in India demonstrate the problematics of living in a hybrid situation. His loyalties and self-autonomy clash with one another. He steps into "a whirl" of questions about his cultural identity until his head "swam" (p.176). Kipling, however, makes his genetics, or "white blood" as he calls it, the source of his redemption. He escapes from falling into the underworld of the natives by "go[ing] native altogether" (p.177).

Hence, Kim's decision to become a coloniser re-forms the structure of the binary Native-Kim/English-Kim and reinforces it stronger than before thus stopping the 'play' of the 'centre'. Derrida states that "the absence of play and différance [is] another name for death" (Derrida 1978:297). Kim dies metaphorically after making his decision. He assumes his new position as a coloniser after he reclines beside the bullock-cart. Said explains that Kipling "renders a powerful, almost instinctive desire to restore the child to its mother in a pre-conscious, undefiled, asexual relationship" when he makes Mother Earth cure Kim. "“[S]he breathed through him to restore the poise he had lost'" (Said 1989:21). Even the land itself, India, is not immune to Kim's charms. Hence, Kipling's India does not object to Kim's presence as a coloniser like that of E. M. Forster's in A Passage to India in which the land and the sky object to the friendship between Aziz and Fielding. ${ }^{23}$

After delivering the documents to Hurree, "Kim begins to feel, in Othello's words, the loss of his occupation". Said explains that "Kim has died to this world, has, like the epic hero, descended to a sort of underworld from which, if he is to emerge, he will arise stronger than before"24 (Said, p.18). Kim does "arise stronger

\footnotetext{
${ }_{23}$ "[T]he temples, the tank, the jail, the palace, the birds, the carrion, the Guest House, that came into view as they issued from the gap and saw Mau beneath: they didn't want it, they said in their hundred voices, 'No, not yet,' and the sky said, 'No, not there.'" (Forster's $A$ Passage to India, pp.315-16)

${ }^{24}$ The "underworld" Said refers to justifies the lama's depiction as an embodiment of the "powers of darkness" (p.123). In effect, the lama is like Hades, king of the Underworld, and Kim is like Persophone. Kim's genetics save him from the lama's world like the pomegranate seed saves Persophone from Hades.
} 
than before" as an embodiment of the colonial power. He, therefore, "must be given a station in life commensurate with his stubbornly fought-for identity" (Said, p.17). He 'evolves' as a coloniser, and this demonstrates that people are 'genetically' different and that "[o]nce a Sahib, always a Sahib"25 (p.151). He eventually realises the futility of trying to escape his 'white blood'.

\section{Conclusion}

Kipling's Kim contains an embedded colonial discourse. The discussions in this chapter clearly demonstrate Kipling's promotion and legitimisation of the British presence as a colonial power in India. He promotes the colony-born Sahibs, not the "imported" ones, and nominates them as the best ones for understanding and dealing with the natives. The analysis of the novel reveals the negative stereotyping of the natives, which is in sharp contrast with the representation of European characters. Kipling negatively represents the natives to justify their colonisation. The natives are depicted as being in desperate need for the colonisers' gift of "thunder and lightning" (Kimbrough 1971:57). To Said, "Kim is a master work of imperialism .... On the one hand, surveillance and control over India; on the other, love for and fascinated attention to its every detail" (Said 1989:45). Kipling uses his knowledge of India to 'market' his colonial ideology thus bringing into focus the knowledge/power binary.

The discussions in this article reveal Kipling's racist attitude towards the natives. They also demonstrate the way ethnology is mobilised to render the natives 'genetically' inferior to the colonisers, and to keep their dominance over them. Like any colonial institution, the British government aimed at alienating the natives by

\footnotetext{
${ }^{25}$ Patrick Williams states that "distinctions are blurred in order to be more strictly redefined ... the central tenet, that Sahibs can and must continue to rule India, goes unquestioned" (Williams et al. 1994:494). The idea is also emphasised when Kim is able to resist losing consciousness at Huneefa's due to "his White blood" (p.255). Further, Huneefa's "dead eyes
} 
the effects of "cultural bomb"26. Fear and inferiority make the colonised stop participating in history and in decision-making, because they start to believe that they were not 'cut out for it', and hence they achieve the colonisers' desire. The British government also aimed at creating a "race of angels" ${ }^{27}$ detached from their past and from their culture. These 'unhappy products' are the race of angels whom colonisation aims at creating and then rejecting.

Further, the novel promotes the myth of the white man. The 'presence' of the white man becomes a must for the success of any social or, as in the case of the lama's search, personal quest. Religion, too, is mobilised by colonisation and becomes an exclusive discourse that labels the natives as 'heathens'. Furthermore, Kipling makes a plea for stopping the process of hybridism. To him, hybridism creates "monstrous" "products" suffering from an inferiority complex and who are incapable of achieving a white man's status. Kim's identity crisis is also mobilised to promote the theme that no white man can escape his 'white blood', and, by the same token, no native can escape his nativity. Using hybridity, Kipling blurs the lines between races only to reassert and emphasise them more than before. Colonisation has destructive effects on the culture and identity of the colonised. Hence, there should be no excuse for any country to assume the role of the 'saviour' of the natives, when in reality it is their 'tormentor' and 'oppressor'. This analysis of Kim

turned to the West" while she was "protecting" Kim (p.255) thus suggesting the whereabouts of his home and allegiance.

${ }^{26}$ Ngügï warns of "the cultural bomb" that is "daily unleashed by imperialism against that collective defiance" of the colonised. It "[a]nnihilate[s] a people's belief in their names, in their languages, in their environment, in their heritage of struggle, in their unity, in their capacities and ultimately in themselves." It also makes people "see their past as one wasteland of non-achievement". In this way colonisation manages to detach people from their past and make them adopt the colonisers' model and/or language. This bomb "would stop their own springs of life" and would create "serious doubts about the moral rightness of struggle." With the intent of creating "despair, despondency and a collective death-wish" (Ngügï 1986:3). Ngügï also describes the self-destruction experienced by the colonised because of the loss of identity, culture, past and a desire to emulate the coloniser.

${ }^{27}$ Fanon claims that colonisation eventually produces "individuals without an anchor, without horizon, colourless, stateless, rootless - a race of angels" (Williams et al. 1994:395). 
exposes the role of colonisation in exploiting the natives and keeping them under colonial dominance.

\section{Works Cited}

Carrington, Charles. (1970) Rudyard Kipling- His Life and Work. Harmondsworth: Penguin Books.

Childs, Peter (Ed.). (1999) Postcolonial Theory and English Literature - A Reader. Edinburgh: Edinburgh University Press.

Derrida, Jacques. (1978) "Ellipsis," in Writing and Differance, trans. Alan Bass. London: Routledge, pp.299-300.

Derrida, Jacques. (1991) "At this very Moment in This Work Here I am," in, Between the Blinds, Ed. Peggy Kamuf. Trans. Ruben Berezdivin. New York: Harvester Wheatsheaf, pp. 405-439.

Elbaz, Mikaël, and Helly, Denise (1995) "Modernity and Postmodernity of National Identities", "Ethnicity and Power". Anthropologie et Sociétés, Vol. 19, No.3. Retrieved from: http://www.erudit.org/revue/as/1995/v19/n3/015367ar.pdf February 9, 2007.

Forster, E. M. (1985) A Passage to India. Cambridge: Penguin Classics.

Gross, John (Ed.). (1972) Rudyard Kipling- the man, his work and his world. London: Weidenfeld \& Nicolson.

Hubel, Teresa. (1996) Whose India? The Independence Struggle in British and Indian Fiction and History. Durham: Duke University Press.

Kimbrough, Robert (ed.). (1971) Joseph Conrad: Heart of Darkness. New York: W. W. Norton \& Company, Inc..

Kipling, Rudyard. Kim. (1913) London: Macmillan and Co. Ltd.

Lycett's, Andrew. (2000) Rudyard Kipling by Michelle de Kretser, The Weekend Australian Books Review, Jan. 22-23. Review 14.

Mcrone, David, 1997 “Unmasking Brittania”, Nations and Nationalism, Vol. 3, No.4., December.

Memmi, Albert. (1974) The Colonizer and The Colonized. 1965. rpt. London: Souvenir Press.

Ngügï wa Thiong'o. (1986) Decolonising the Mind: The Politics of Language in African Literature. London: James Currey Ltd. 
Rubin, David. (1986) After the Raj-British Novels of India Since 1947. Hanover: University Press of New England.

Said, Edward (Ed.). (1989) Rudyard Kipling-Kim. Penguin Books Ltd.

Said, Edward. (1987) Orientalism. London: Penguin.

Sarup, Madan. (1996) Identity, Culture And The Postmodern World. Edinburgh: Edinburgh University Press Ltd.

Singh, M. A. Bhupal. (1974) A Survey of Anglo-Indian Fiction. London: Curzan Press Ltd.

Sunderland, Lynn. (1989) The Fantastic Invasion- Kipling, Conrad and Lawson. Melbourne: Melbourne University Press.

Williams, Patrick. and Chrisman, Laura (eds.). (1994) Colonial Discourse and Postcolonial Theory- A Reader. London: Harvest Wheatsheaf. 